\title{
Protection of Wine from Protein Haze Using Schizosaccharomyces japonicus Polysaccharides
}

\author{
Valentina Millarini ${ }^{1}$, Simone Ignesti ${ }^{1}{ }^{\circledR}$, Sara Cappelli ${ }^{1}$, Giovanni Ferraro ${ }^{2}{ }^{\circledR}$, \\ Alessandra Adessi ${ }^{1}$ (D) Bruno Zanoni ${ }^{1}$ (D) Emiliano Fratini ${ }^{2}$ (D) and Paola Domizio ${ }^{1, *}$ \\ 1 Department of Agriculture, Food, Environment and Forestry (DAGRI)-University of Florence, \\ P.le delle Cascine 18, 50144 Florence, Italy; valentina.millarini@unifi.it (V.M.); \\ simone.ignesti@gmail.com (S.I.); saracappelli11194@gmail.com (S.C.); alessandra.adessi@unifi.it (A.A.); \\ bruno.zanoni@unifi.it (B.Z.) \\ 2 Department of Chemistry "Ugo Schiff" and Center for Colloid and Surface Science (CSGI)- \\ University of Florence, Via della Lastruccia 3-13, 50019 Sesto Fiorentino, Italy; \\ giovanni.ferraro@unifi.it (G.F.); emiliano.fratini@unifi.it (E.F.) \\ * Correspondence: paola.domizio@unifi.it
}

Received: 23 August 2020; Accepted: 29 September 2020; Published: 3 October 2020

\begin{abstract}
Nowadays commercial preparations of yeast polysaccharides (PSs), in particular mannoproteins, are widely used for wine colloidal and tartrate salt stabilization. In this context, the industry has developed different processes for the isolation and purification of PSs from the cell wall of Saccharomyces cerevisiae. This yeast releases limited amounts of mannoproteins in the growth medium, thus making their direct isolation from the culture broth not economically feasible. On the contrary, Schizosaccharomyces japonicus, a non-Saccharomyces yeast isolated from wine, releases significant amounts of PSs during the alcoholic fermentation. In the present work, PSs released by Sch. japonicus were recovered from the growth medium by ultrafiltration and their impact on the wine colloidal stability was evaluated. Interestingly, these PSs contribute positively to the wine protein stability. The visible haziness of the heat-treated wine decreases as the concentration of added PSs increases. Gel electrophoresis results of the haze and of the supernatant after the heat stability test are consistent with the turbidity measurements. Moreover, particle size distributions of the heat-treated wines, as obtained by Dynamic Light Scattering (DLS), show a reduction in the average dimension of the protein aggregates as the concentration of added PSs increases.
\end{abstract}

Keywords: wine protein; wine haze; protein stability test; protein stability treatment; mannoprotein; polysaccharide; Schizosaccharomyces japonicus; non-Saccharomyces

\section{Introduction}

The use of bentonite represents the most common method used worldwide for wine protein stabilization [1]. Bentonite acts as a cation exchanger and, by binding to proteins present in the wine through electrostatic interactions, forms complexes that can be then removed by filtration. Although this kind of adjuvant is very effective in removing proteins responsible for haze, it has several drawbacks like the removal of color and flavor compounds [2-4]. Moreover, the disposal of spent bentonite requires extra labor costs and, in addition, presents health problems associated with its management.

Due to the negative implications associated with bentonite, several alternatives to its use have been explored such as flash pasteurization [5,6], ultrafiltration [7,8], addition of proteolytic enzymes $[9,10]$ silica gel, hydroxyapatite and alumina [11], zirconium oxide [12-15], natural zeolites [16,17], chitin and chitosan [18-21], carrageenan [22-24], and yeast mannoproteins [25-30]. These last ones have recently found an increasing interest in the wine industry as a result of the multiple positive effects associated 
with this bio-product: decreasing astringency [31], improving mouth-feel and fullness [32], adding complexity and aromatic persistence [33], increasing sweetness and roundness [34], and reducing protein and tartrate instability $[35,36]$.

Mannoproteins are highly glycosylated proteins, containing $1-10 \%$ of proteins and $85-90 \%$ of carbohydrates, mainly mannose $[37,38]$. Because of their high content of carbohydrates, mannoproteins are normally referred to as polysaccharides. Mannoproteins are present on the outer cell wall layer of yeast and are released during alcoholic fermentation and wine aging processes [39-42].

A competition between wine proteins and mannoproteins for non-proteinaceous wine components (responsible for wine protein instability) has been reported as the most likely mechanism to explain the improved wine stability obtained through mannoproteins [43].

Although some scientific evidence has already emphasized the positive impact on wine protein stability determined by mannoproteins purified from wine or from yeast cell wall of S. cerevisiae [25-30], the efficacy of most of the commercial exogenous mannoproteins of Saccharomyces is very limited. A different impact on the wine protein stability by eleven commercial mannoprotein preparations was highlighted by Ribeiro et al. [44]. Interestingly, it was found that mannoproteins with a low mannose-to-glucose ratio were not able to stabilize wine against protein instability, highlighting that their performances are strictly related to the different chemical composition and the different degrees of purity, or more practically to the extraction and purification methods adopted by individual manufacturers.

Various processes for the isolation and purification of mannoproteins can be applied, such as enzymatic treatments (to release them from the cell wall) and acids or hot alkali usage (to solubilize proteins). However, these extraction methods can affect the structural features and molecular weight of these macromolecules and, in turn, can significantly affect their bioactivity [45]. On the other hand, the extraction of mannoproteins from the cell wall of Saccharomyces yeasts allows a higher yield as compared to their recovery from the fermentation medium. Indeed, Saccharomyces yeasts, during alcoholic fermentation, release a rather low quantity of mannoproteins, normally ranging from 50 to $175 \mathrm{mg} / \mathrm{L}$ [29,46]. However, yeasts other than Saccharomyces are able to release larger amounts of polysaccharides (PSs) [47-52]. In particular, Domizio et al. [51] have shown that yeasts belonging to the species Schizosaccharomyces japonicus were able to release a high quantity of polysaccharides in the fermentation medium. In particular, the strains Sch. japonicus \# UCD2489 released an amount of PSs $\sim 7$ times higher than that released by a commercial Saccharomyces cerevisiae yeast strain under the same fermentative conditions. Interestingly, Domizio et al. [53], in a study carried out using mixed fermentation of Sch. japonicus/S. cerevisiae, found that polysaccharides released by Sch. japonicus were able to protect wine from protein haze.

The possibility of recovering these macromolecules directly from the growth media by ultrafiltration would overcome the necessity of the extraction of PSs from the cell wall, maintaining their native structure unaltered. Based on these observations, the aim of this study was to evaluate the impact of Sch. japonicus \# UCD2489 polysaccharides on wine protein stability.

\section{Materials and Methods}

\subsection{Yeast Strains}

A yeast strain belonging to the species Sch. japonicus (UCD2489) from the yeast culture collection of the Department of Viticulture and Enology University of California, Davis, was used.

\subsection{Wine}

Vernaccia di San Gimignano, a Tuscan white wine, was used in the present study to assess the impact of Sch. japonicus polysaccharides on wine protein stability. Table 1 shows the main chemical characteristics of Vernaccia wine, as obtained by Fourier-transform infrared spectroscopy (FT-IR) (FOSS WineScan, FT 120 Reference Manual, Foss, Hamburg, Germany). 
Table 1. Main analytical parameters of the Vernaccia wine used in the present study.

\begin{tabular}{cc}
\hline Chemical Parameters & Values \\
\hline $\mathrm{pH}$ & $3.33 \pm 0.07$ \\
Ethanol \% $(v / \mathrm{v})$ & $12.35 \pm 0.14$ \\
Residual sugars $(\mathrm{g} / \mathrm{L})$ & $0.69 \pm 0.02$ \\
Titratable acidity (as tartaric acid) $(\mathrm{g} / \mathrm{L})$ & $5.14 \pm 0.07$ \\
Volatile acidity (as acetic acid) $(\mathrm{g} / \mathrm{L})$ & $0.23 \pm 0.01$ \\
$\Delta^{*}$ NTU & $14.00 \pm 0.20$
\end{tabular}

* NTU (Nephelometric Turbidity Units) assessed by the heat test, as reported below (Section 2.7).

\subsection{Fermentation Conditions}

Fermentations were carried out at $27^{\circ} \mathrm{C}$ in $500 \mathrm{~mL}$ Erlenmeyer flasks containing $330 \mathrm{~mL}$ of a synthetic polysaccharide-free grape juice "Minimal Must Medium" (MMM) [54], with no addition of Tween 80 and ergosterol. The concentrations of assimilable nitrogen and sugar were $208 \mathrm{mg} / \mathrm{L}$ and $120 \mathrm{~g} / \mathrm{L}$, respectively. The medium was sterilized by filtration. The preculture of Sch. japonicus \# UCD2489 was grown in $10 \mathrm{~mL}$ of the same modified synthetic medium at $27^{\circ} \mathrm{C}$ for $72 \mathrm{~h}$, and then used to inoculate the fermentations at the optical density of $0.1\left(\mathrm{OD}_{600} \mathrm{~nm}\right)$. The flasks, closed with a cotton plug, were continuously agitated at $150 \mathrm{rpm}$ in an orbital shaker. The fermentation kinetic was monitored by weight loss, due to $\mathrm{CO}_{2}$ production, and was followed for ten days.

\subsection{Polysaccharides Recovery and Purification}

After ten days of alcoholic fermentation, cells were removed by centrifugation $\left(8000 \mathrm{~g}, 4{ }^{\circ} \mathrm{C}\right.$, $15 \mathrm{~min}$ ) and the supernatant was filtered through $0.45 \mu \mathrm{m}$ acetate cellulose membranes. Afterwards, the filtered supernatant was dialyzed and concentrated using an ultrafiltration unit (Amicon ${ }^{\circledR}$-stirred cell 8200, Millipore, Bedford, MA, USA) equipped with a polyethersulphone membrane with a $10 \mathrm{kDa}$ molecular weight cut-off (PBGC06210, Millipore, Bedford, MA, USA). The ultrafiltration was carried out using a $\mathrm{N}_{2}$ pressure of around $\sim 30 \mathrm{psi}$. The retentate was collected and freeze-dried for $48 \mathrm{~h}$ (Edwards Modulyo freeze-dryer, Edwards, Crawley, UK).

\subsection{Wine Treatments}

Increasing concentrations of freeze-dried polysaccharides (UFS) were added into the Vernaccia wine. In particular, $1 \mathrm{~g} / \mathrm{L}$ of UFS was resuspended in the Vernaccia wine (stock solution) and then diluted (using the same wine) to prepare different aliquots at lower concentrations (100 mg/L; $200 \mathrm{mg} / \mathrm{L}$; $300 \mathrm{mg} / \mathrm{L} ; 400 \mathrm{mg} / \mathrm{L}$ and $600 \mathrm{mg} / \mathrm{L}$ ). Three aliquots of each concentration were prepared. All the operations were performed in a laminar flow hood to prevent microbial and dust contamination.

\subsection{Polysaccharides Characterization}

\subsubsection{Polysaccharides Quantification}

The concentration of PSs was evaluated by high-performance liquid chromatography (HPLC), according to the method reported in Romani et al. [55]. After filtration through $0.45 \mu \mathrm{m}$ nitrocellulose membranes, $20 \mu \mathrm{L}$ of sample were injected into the HPLC apparatus (Varian Inc., Palo Alto, CA, USA) equipped with a 410 series autosampler, a 210 series pump, and a 356-LC refractive index detector. Isocratic separation was performed on a TSK G-OLIGO-PW (808031) column (30 cm $\times 7.8 \mathrm{~mm}$ i.d.) and a TSK-GEL OLIGO (808034) guard column $(4 \mathrm{~cm} \times 6 \mathrm{~mm}$ i.d.) (Supelco, Bellefonte, PA, USA). The mobile phase was $0.2 \mathrm{M} \mathrm{NaCl}$, at a flow rate of $0.8 \mathrm{~mL} / \mathrm{min}$. Peaks were quantified by comparison with an external calibration curve of mannan (Sigma-Aldrich, Milan, Italy) from $50 \mathrm{mg} / \mathrm{L}$ to $1000 \mathrm{mg} / \mathrm{L}$. The analysis of the peaks was performed using the software Galaxie Chromatography Data System (version 1.9.302.530) (Varian Inc., Palo Alto, CA, USA). All the analyses were carried out in duplicate. 


\subsubsection{Monosaccharide Composition}

Polysaccharides were first hydrolyzed with trifluoroacetic acid (TFA). In particular, $5 \mathrm{mg}$ of UFS were mixed with $2 \mathrm{~mL}$ of a $2 \mathrm{~N}$ TFA solution and heated at $120^{\circ} \mathrm{C}$ for $120 \mathrm{~min}$. TFA was then removed using a rotary evaporator and the dried extracts were re-solubilized in deionized water. This operation was repeated three times per sample.

The monosaccharidic composition of the hydrolyzed fraction was analyzed using Ion Exchange Chromatography (IEC) following the procedures described by Chamizo et al. [56]. A Dionex ICS-2500 ion exchange chromatograph, equipped with an ED50 pulsed amperometric detector operating with a gold working electrode, was used. Each sample was injected into a Dionex CarboPacPA1 column $(4.6 \times 250 \mathrm{~mm}$, Thermo Scientific, Waltham, MA, USA). The eluents HPLC-grade water (A), $0.185 \mathrm{M}$ $\mathrm{NaOH}(\mathrm{B})$, and $0.488 \mathrm{M}$ sodium acetate (C), were mixed as follows: from injection time to $20 \mathrm{~min}$ $A: B=90: 10$; from 20 to $30 \mathrm{~min} B: C=50: 50$; from 30 to $60 \mathrm{~min}, \mathrm{~A}: B=90: 10$. The flow rate was kept at a constant value of $1 \mathrm{~mL} / \mathrm{min}$. The different sugars were identified on the basis of the retention time of known standards. Results were expressed as molar ratio (\%).

\subsubsection{Protein Quantification}

The freeze-dried polysaccharides (UFS) were rehydrated with a known amount of distilled water for protein quantification. Quantitative determination of proteins was assessed by dye-binding Bradford assay [57] using bovine serum albumin (BSA) (Sigma-Aldrich, Milan, Italy) and dye reagent (Bio-Rad Laboratories, Hercules, CA, USA) for the calibration curve.

\subsection{Wine Protein Heat Test and Treatment of the Derived Fractions}

Protein stability was assessed by determining the induced haze value following the heat test according to McRae et al. [58]. Briefly, wine aliquots were first filtered $(0.45 \mu \mathrm{m}$, acetate cellulose membranes) and then heated at $80^{\circ} \mathrm{C}$ for $2 \mathrm{~h}$. Successively, these aliquots were cooled at $4{ }^{\circ} \mathrm{C}$ for $16 \mathrm{~h}$ and left at room temperature for $2 \mathrm{~h}$ before measuring the turbidity. Wine turbidity was determined with a nephelometer (HI88703 turbidimeter, Hanna Instrument Inc., Woonsocket, USA). Data were analyzed by One-way ANOVA and Tukey's post-test, setting $p$ value to 0.05 .

After the heat test, the wines were centrifuged in order to separate the haze fraction (HF) from the supernatant fraction (SF). Whereupon, SF was added with four volumes of cold $95 \%$ ethanol containing $\mathrm{HCl} 0.3 \mathrm{M}$ and kept at $4{ }^{\circ} \mathrm{C}$ for $24 \mathrm{~h}$ to precipitate the polysaccharides. After centrifugation $(9000 \times \mathrm{g}$, $4{ }^{\circ} \mathrm{C}, 30 \mathrm{~min}$ ), the supernatant was discarded, and the pellet was washed twice with four volumes of $96 \% v / v$ cold ethanol and finally vacuum-dried at room temperature. The dried pellet was then rehydrated with distilled water for the successive proteins profiling characterization. Instead, HF was added to the sodium dodecyl sulfate sample buffer.

\subsection{Proteins Profiling by Gel Electrophoresis}

Detection of proteins was performed by using $10 \%$ sodium dodecyl sulfate-polyacrylamide gel electrophoresis (SDS-PAGE) [59]. In particular, $20 \mu \mathrm{L}$ of sample was treated with $6.65 \mu \mathrm{L}$ of $4 \mathrm{X}$ Laemmlli buffer (Bio-Rad) and $2.75 \mu \mathrm{L}$ of $1 \mathrm{M}$ dithiothreitol (DTT) (Acros Organics, Geel, Belgium ) and then heated at $95^{\circ} \mathrm{C}$ for $5 \mathrm{~min}$. Afterwards, $15 \mu \mathrm{L}$ of the mixture was loaded onto the gel. Blue precision plus protein standard (Bio-Rad) was loaded. The SDS-PAGE was performed using a Mini Protean II apparatus (Bio-Rad) (45 V within the stacking gel and $104 \mathrm{~V}$ in the developing gel). The protein bands in the gels were stained with Bio-Safe Coomassie G-250 stain (Bio-Rad). Instead, glycoproteins were detected with the periodic acid Schiff's reagent (Sigma-Aldrich) applying the procedure described by Packer et al. [60]. Briefly, the SDS gel was fixed in 50\% (v/v) ethanol for $30 \mathrm{~min}$, washed in distilled water for $10 \mathrm{~min}$ and then incubated for $30 \mathrm{~min}$ in a solution of periodic acid 1\% (v/v) and acetic acid 3\% $(v / v)$. Afterwards, the gel was washed in distilled water and then in $0.1 \%(w / v)$ sodium metabisulfite solution $(10 \mathrm{mM} \mathrm{HCl})$. The gel was then stained with Schiff's reagent in the dark for $1 \mathrm{~h}$. Afterwards, 
the gel was incubated for $1 \mathrm{~h}$ in $0.1 \%(w / v)$ sodium metabisulfite solution $(10 \mathrm{mM} \mathrm{HCl})$ and finally washed several times in $0.5 \%(w / v)$ sodium metabisulfite $(10 \mathrm{mM} \mathrm{HCl})$ solution. Peroxidase from horseradish (Sigma-Aldrich, Milan, Italy) was used as a positive control and BSA as a negative control.

\subsection{Dynamic Light Scattering (DLS)}

Dynamic light scattering (DLS) measurements were carried out on a Brookhaven system. The light source was the second harmonic of a diode Nd:YAG laser (Torus laser, mpc3000, Laser Quantum, Cheshire, UK) $(\lambda=532 \mathrm{~nm})$ and the scattered intensity was detected by an avalanche photodiode detector (BI-APD) The samples were placed in glass tubes and immersed in a thermostatic unit filled with decahydronaphthalene to match the glass refractive index. The autocorrelation functions (ACF) were analyzed through the Laplace inversion according to a CONTIN algorithm [61].

\section{Results and Discussion}

\subsection{Fermentation Performance}

Sch. japonicus \# UCD2489 showed a low fermentative activity. After five days of alcoholic fermentation, it reached the maximum quantity of $\mathrm{CO}_{2}$ produced $(\sim 4.2 \mathrm{~g} / 100 \mathrm{~mL})$ (data not shown). These results are in agreement with those previously observed with Sch. japonicus \# UCD2489 during the alcoholic fermentation carried out using the same synthetic grape juice but containing a higher sugar concentration $(220 \mathrm{~g} / \mathrm{L})[51]$.

\subsection{Polysaccharides Quantification and Characterization}

After ten days of alcoholic fermentation, the quantity of PSs released by Sch. japonicus in the medium was $1.23 \pm 0.06 \mathrm{~g} / \mathrm{L}$. Figure 1 shows the monosaccharidic composition of the freeze-dried polysaccharide (UFS). The experimental data highlighted a high percentage of mannose $(53.8 \pm 1.5 \%)$ and similar percentages of galactose $(21.1 \pm 1.7 \%)$ and glucose $(23.9 \pm 0.7 \%)$. Instead, the percentages of glucosamine $(0.6 \pm 0.1 \%)$ and proteins $(0.8 \pm 0.1 \%)$ were very low. These results confirm the ability of Sch. japonicus yeast to release a high quantity of polysaccharides in the growth medium [51] as compared to $0.05-0.175 \mathrm{~g} / \mathrm{L}$ usually obtained by Saccharomyces yeasts $[16,20]$. Domizio et al. [51] found a similar composition of monosaccharides and proteins in the PSs released by the same strain of Sch. japonicus during the alcoholic fermentation in the same type of synthetic grape juice, but containing Tween 80, ergosterol and a higher sugar concentration. These results are also consistent with the chemical composition of the cell wall of Schizosaccharomyces genus, containing galactomannans in the outer layer [62].

The pattern of the UFS proteins, as analyzed by SDS PAGE, is reported in Figure 2. Total protein profiles were displayed using the Bio-Safe Coomassie G-250 stain (Figure 2a). This analysis revealed a band centered around $32 \mathrm{kDa}$ and bands with molecular-mass greater than $250 \mathrm{kDa}$. The gel staining with Schiff's reagent (PAS) (Figure 2b) highlights that the high molecular bands corresponded to glycosylated proteins. Instead, the band around $32 \mathrm{kDa}$, present in the gel stained with Coomassie, was not evident in the one stained with PAS. In a previous paper, Domizio et al. [51], analyzing the protein profile of the polysaccharides released in the medium by Sch. japonicus \#UCD2489, showed that the band around $32 \mathrm{kDa}$ corresponded to a glycosylated protein, as demonstrated after gel staining with the Pro-Q Emerald 488 gel stain kit specific for glycoproteins. Considering that Pro-Q Emerald 488 is roughly $8-16$-fold more sensitive than the Schiff's reagent [63], the band around $32 \mathrm{kDa}$, even if it is not evidenced by PAS (Figure 2b), could be associated to a glycoprotein. 


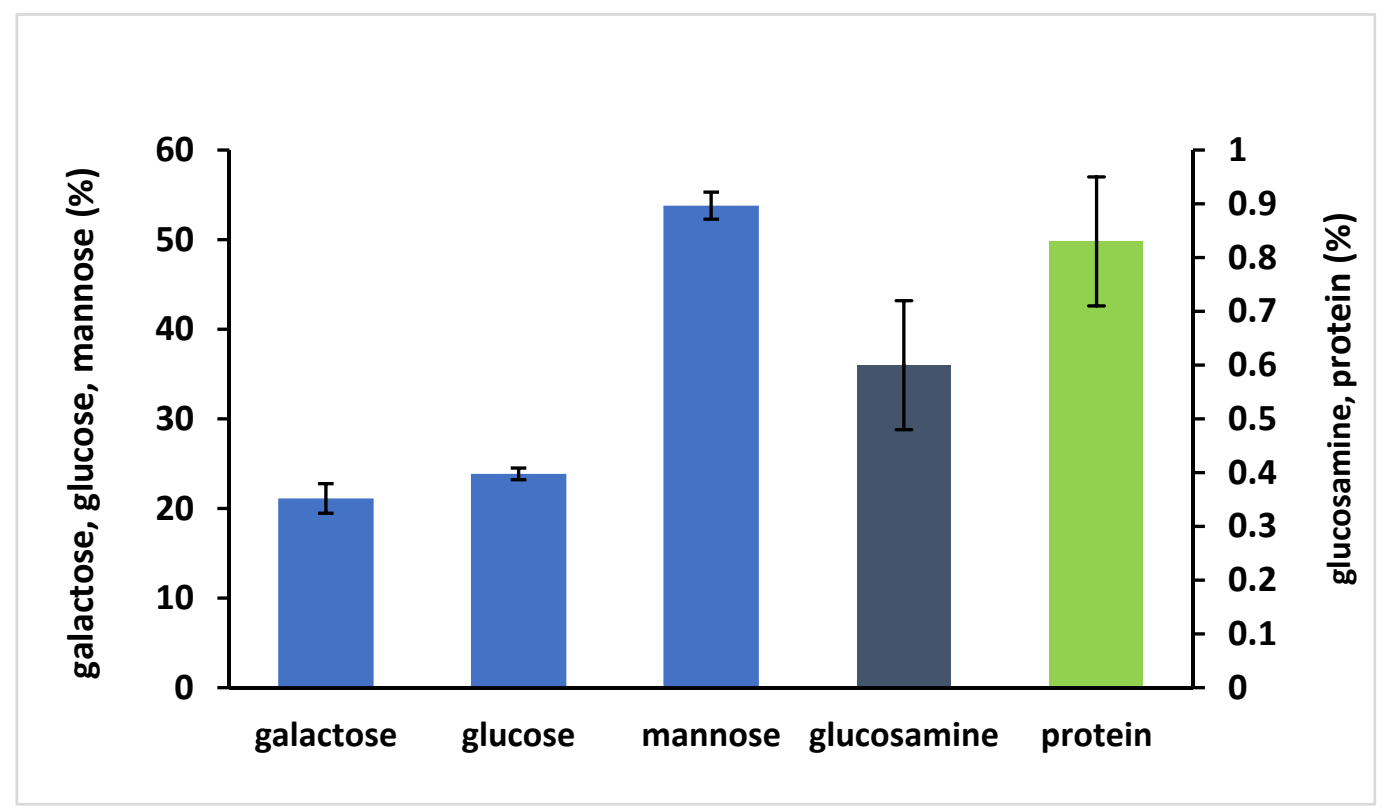

Figure 1. Monosaccharidic composition (expressed as mol \%) and proteins content of the freeze-dried polysaccharides (UFS). Error bars represent standard deviation of three analytical replicates, each referred to as experimental duplicates.

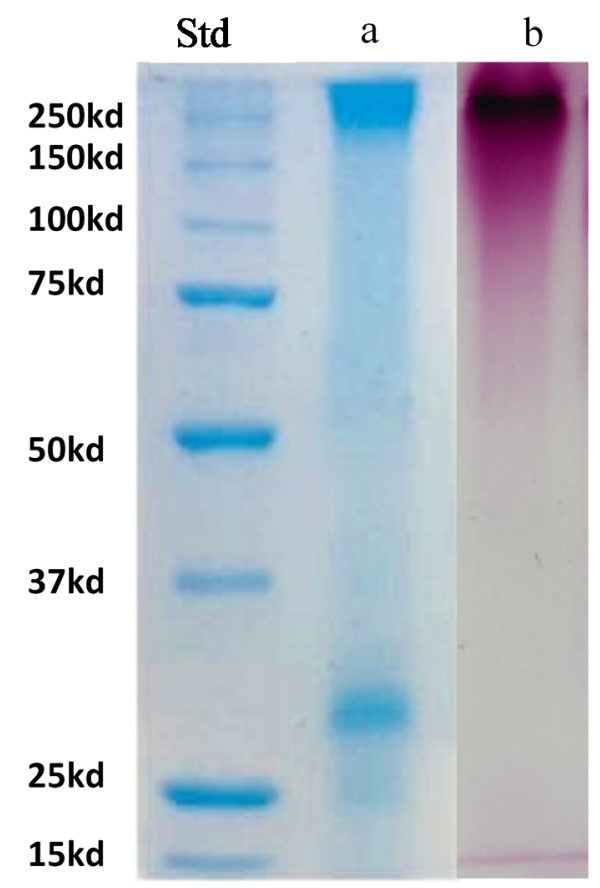

Figure 2. Sodium dodecyl sulfate-polyacrylamide gel electrophoresis (SDS-PAGE) of the freeze-dried polysaccharides (UFS). The glycoproteins were stained on the electrophoretic gel with Bio safe Coomassie (a) and with Schiff's reagent (b). Std: Blue precision plus molecular weight standards.

\subsection{Impact of PSs on Wine Protein Stability}

The impact of increasing concentrations of Sch. japonicus polysaccharides (UFS) on heat-induced protein haze formation in the Vernaccia wine was assessed by nephelometry and dynamic light scattering. All the measurements were also performed on a control sample (i.e., an aliquot of wine where UFS was not added). Figure 3 shows the difference in nephelometric turbidity units ( $\triangle N T U)$ between heated and unheated samples as a function of the different amounts of UFS added. One-way 
ANOVA and Tukey's post-test showed significant differences for all samples, except for 300, 400, and $600 \mathrm{mg}$ treatments $(p=0.05)$. The control sample showed a $\triangle$ NTU of $14.4 \pm 0.3$. The visible haziness induced by heating, due to the destabilization/aggregation of proteins naturally present in the wine, decreases as the concentration of added PSs increases, revealing an inverse exponential relationship between the level of haze protection and the concentration of the additive. In particular, the addition of $100 \mathrm{mg} / \mathrm{L}$ of UFS resulted in a $14 \%$ reduction in haziness compared to untreated wine (control). A further $20 \%$ decrease was observed following the addition of an extra $100 \mathrm{mg} / \mathrm{L}$ of UFS. Further additions of UFS result in lesser percentage decrease in haziness, reaching a 50\% total reduction compared to the control with the addition of $600 \mathrm{mg} / \mathrm{L}$ of UFS. A similar relationship between turbidity and concentration of macromolecules with haze protective activity was observed also by other authors $[26,29,64]$.

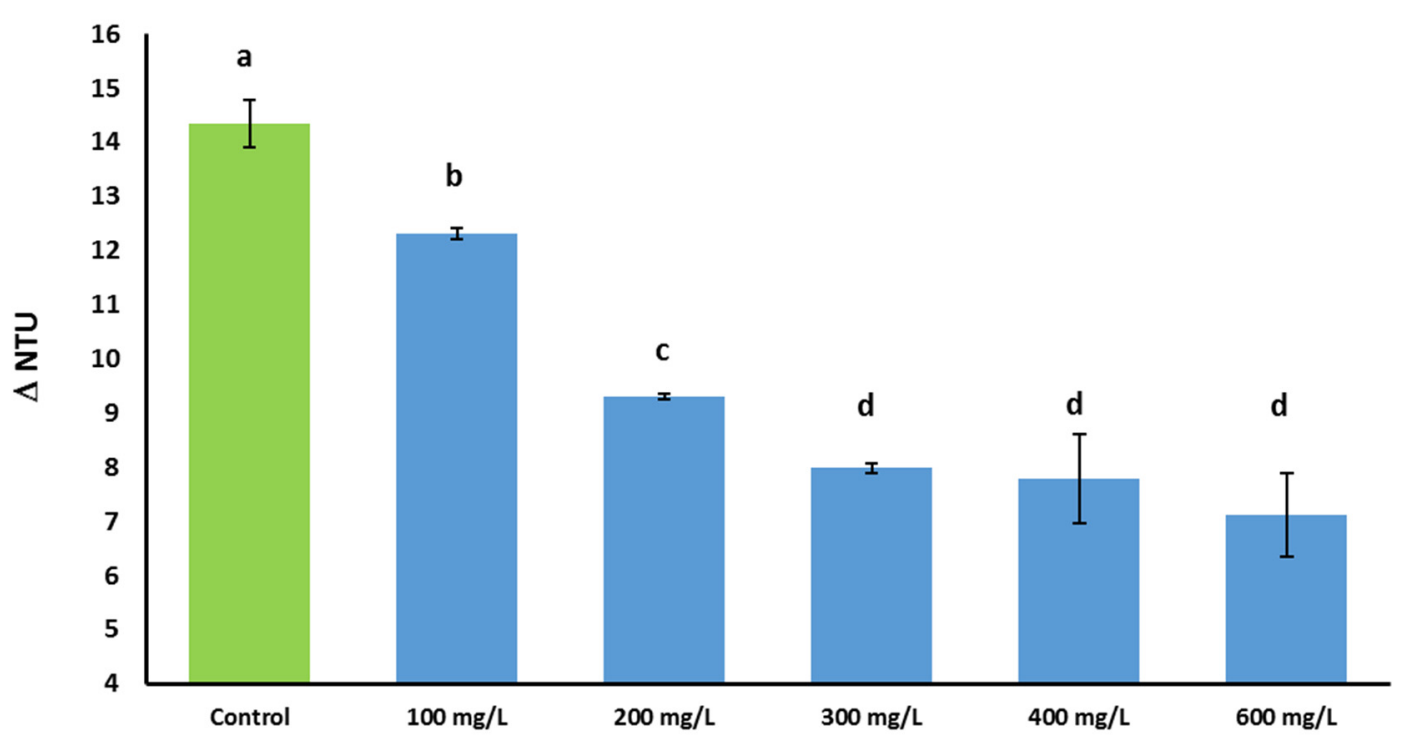

Figure 3. Haziness of Vernaccia wine added with increasing amounts of UFS (from $100 \mathrm{mg} / \mathrm{L}$ to $600 \mathrm{mg} / \mathrm{L}$ ) as obtained by nephelometry after heating treatment. Control: Vernaccia wine without UFS. Error bars represent standard deviation of three independent experiments, each carried out in duplicate. Values displaying different letters $(a, b, c, d)$ are significantly different (One-way ANOVA, Tukey's post-test, $p=0.05$ ).

Taking into account that wines are usually considered protein stable when the difference in turbidity between heated and unheated controls are less than $2 \Delta$ NTU [65], these results show that the addition of $300 \mathrm{mg} / \mathrm{L}$ of PSs into a wine is able to reduce protein haze to around $50 \%$ of the initial value.

Figure $4 a-d$ show the electrophoretic profiles of Vernaccia wine (before the heat test) and of the two fractions (HF and SF) obtained after centrifugation of the heat-treated wines added with increasing amount of UFS. The bands around $20-28 \mathrm{kDa}$, present in the protein profile of Vernaccia wine before the heat test (Figure 4a), could be assigned to grape-derived proteins (PR-proteins), such as chitinase and thaumatin-like proteins (TLPs) [66-68]. PR-proteins are considered the main cause of protein haze in white wine, which can occur with extended storage at elevated temperatures $[68,69]$. 


$250 \mathrm{kDa}$
$150 \mathrm{kDa}$
$100 \mathrm{kDa}$
$75 \mathrm{kDa}$
$50 \mathrm{kDa}$
$37 \mathrm{kDa}$
$25 \mathrm{kDa}$
$15 \mathrm{kDa}$

$\mathbf{a}$

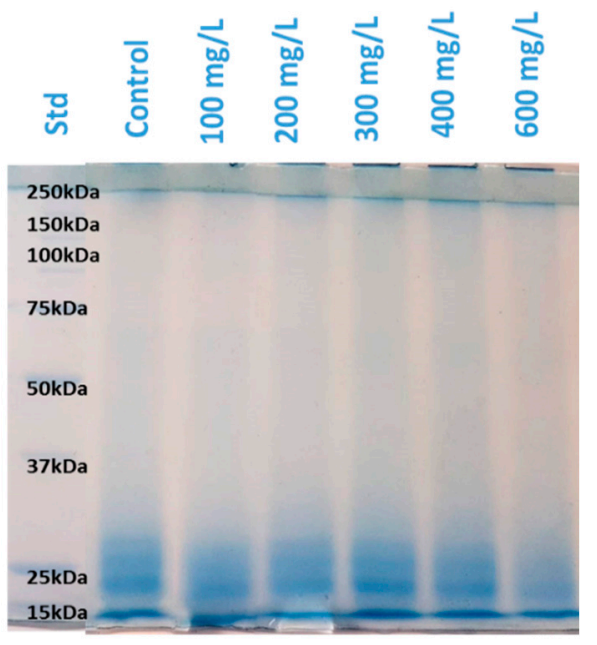

b

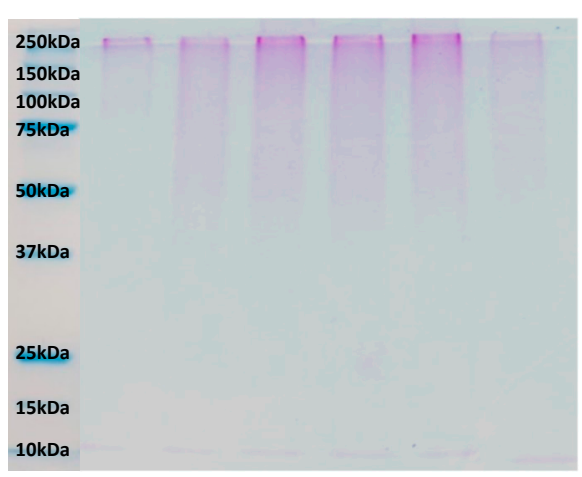

d

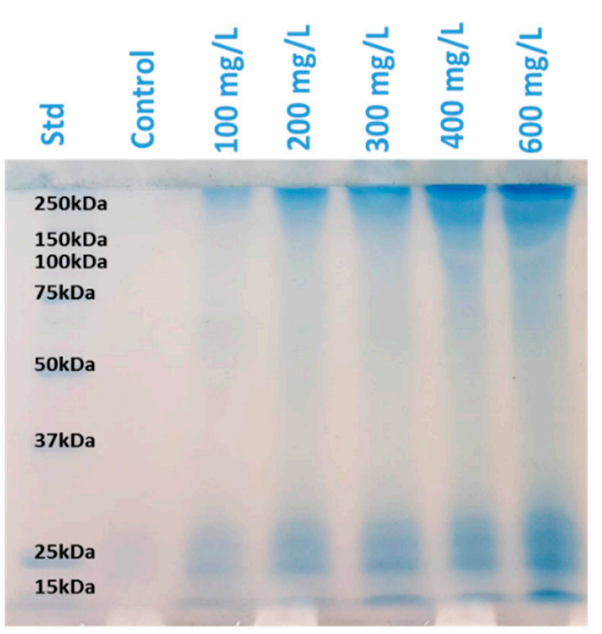

c

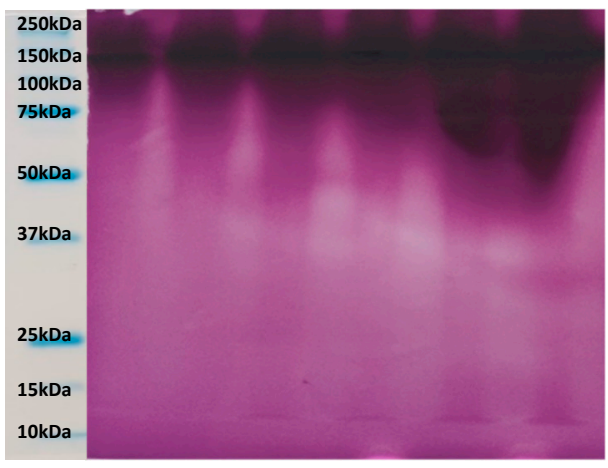

$\mathbf{e}$

Figure 4. SDS-PAGE electrophoresis of Vernaccia wine proteins before the heat stability test (a) and of the two fractions, haze (HF) (b-d) and supernatant (SF) (c-e), obtained after centrifugation of the wines added with increasing amount (mg/L) of freeze-dried polysaccharides (UFS) and heat treated. Control: Vernaccia wine with no UFS addition. The proteins were stained on the electrophoretic gel with Bio safe Coomassie $(\mathbf{b}, \mathbf{c})$ and with Schiff's reagent $(\mathbf{d}, \mathbf{e})$. Std: Blue precision plus molecular weight standards.

SDS-PAGE analysis of the haze fraction (HF) (Figure $4 \mathrm{~b}$ ), showed the presence of proteins bands only within the range of 20-28 kDa. This result emphasizes the heat instability of these proteins, in agreement with their supposed nature as PR proteins. Moreover, as the level of PSs addition increased, a small decrease of the intensities of these bands was observed. In contrast, the added PSs appeared to remain soluble and stable after heating. Indeed, the bands with a molecular-mass greater than $250 \mathrm{kDa}$, corresponding to those of the added PSs, were clearly lacking in the haze fractions (HF) (Figure 4b) and present in the supernatant fractions (SF) (Figure 4c). Interestingly, an increase in the level of added PSs generates an increase in the intensities of the relevant bands and of those corresponding to $20-28 \mathrm{kDa}$ (Figure 4c). These findings highlight the heat stability of Sch. japonicus PSs and their ability to maintain partially the other proteins dispersed, even at elevated temperatures. In contrast, other authors found that, regardless of the addition of invertase or mannoproteins purified from wine, all the grape-derived protein precipitated after heating [26,29].

Instead, the band at $32 \mathrm{kDa}$, ascribable to the UFS polysaccharides (Figure 2a), was not evident in the gels of both fractions (HF and SF) of the heated wine. This could be due to an interaction of denatured proteins with soluble proteins in a co-precipitation mechanism. 
The haze and supernatant fractions analyzed by SDS-PAGE were also visualized using the PAS carbohydrate stain (Figure $4 \mathrm{~d}$,e). While in the gel of the haze fractions no evident bands were present, the supernatant fractions showed a positive response to the carbohydrate stain, with an increase of the band intensities related to the proteins with molecular-mass greater than $250 \mathrm{kDa}$ as the concentrations of UFS increased. These results confirm that no glycoproteins were present in the haze fraction and that the proteins present in UFS fraction were glycosylated.

Although wine protein solubility likely increased as the concentration of added PSs increased, a plateau in the haziness reduction was observed for UFS doses higher than $300 \mathrm{mg} / \mathrm{L}$. Indeed, similar residual haze values in the heated wine were detected by the nephelometer at UFS concentrations higher than $300 \mathrm{mg} / \mathrm{L}$. Thus, the heat-induced aggregation process of a portion of proteins seems to be independent from the added PSs. On the other hand, other physico-chemical factors might be involved in the protein aggregation process [68]. Among these, $\mathrm{pH}$ can strongly affect the stability of wine proteins $[70,71]$ since wine proteins are positively charged at wine $\mathrm{pH}$ and electrostatic attractions with negative charged compounds might determine colloidal instability (protein aggregation and precipitation) [71]. Yeast mannoproteins are reported to be neutral or negatively charged and their density was directly correlated to their phosphorus content [72]. Considering that $\mathrm{pH}$ can also affect the charge of some polysaccharides [71,72], further studies are still needed to evaluate the charge density profile of the Schizosaccharomyces' galactomannoproteins in the wine to better understand the mechanism at the base of their interference with wine proteins.

Dynamic light scattering (DLS) was also performed on the heat-treated samples of wine to determine the size distribution of the suspended aggregated proteins. DLS measures the Brownian motion of the objects in the sample and relates this to the size of the particles [73]. Figure 5a reports the correlation functions for all the investigated samples, while Figure $5 b$ shows the mean diameters obtained from the fitting of the curves with the CONTIN algorithm together with the number of scattered photons expressed as kilocounts per second (kcps). The comparison between the number of scattered photons in the heated and not-heated samples is shown in Figure 5c.

The presence of scattering objects in the heated samples can be ascribed to the formation of protein aggregates induced by thermal treatment. Indeed, the comparison between the number of scattered photons in the wine aliquots before and after heating (Figure 5c) confirms the lower number of aggregates in the as-prepared wine samples. Interestingly, the size of the haze particles decreased as the concentration of added polysaccharides increased (Figure 5b). The relationship between the haze particle size and PSs concentration is similar to that found for the turbidity (i.e., exponential function), with the decrease in particle size of the aggregate diminishing to less than $0.3 \mu \mathrm{m}$ at the highest addition of PSs. As a consequence of this reduction, the haze was barely detectable with the naked eye. Variation of $\triangle \mathrm{NTU}, \mathrm{kcps}$ and mean diameter of the aggregate could be modeled by the function: $y(C)=y_{0}+\operatorname{Aexp}-\left(C / C^{*}\right)$, where the $y_{0}$ is the baseline of the exponential, $A$ is its amplitude and $C^{*}$ represents the critical concentration of additive able to reduce the destabilization phenomenon by a factor $1 / \mathrm{e}$. $\mathrm{C}^{*}$, resulting from the fits of three curves, is in the range $100-200 \mathrm{mg} / \mathrm{L}$.

These findings are in good agreement with the evidence found by Waters et al. [26] that reported an exponential relationship between haze particle size and the concentration of a crude haze protective factor, with a particle size reduction from $30 \mu \mathrm{m}$ to $5 \mu \mathrm{m}$.

The release of a high quantity of polysaccharides in the media makes this non-Saccharomyces yeast particularly interesting for the industrial production of exogenous polysaccharide preparations that could be then easily purified by ultrafiltration and used for winemaking purposes such as protein stability. Indeed, the possibility to recover high amounts of these compounds directly from the fermentation medium, without using enzymatic treatments or other processes to separate the PSs from the cell wall, could make these yeasts convenient from a production perspective. 

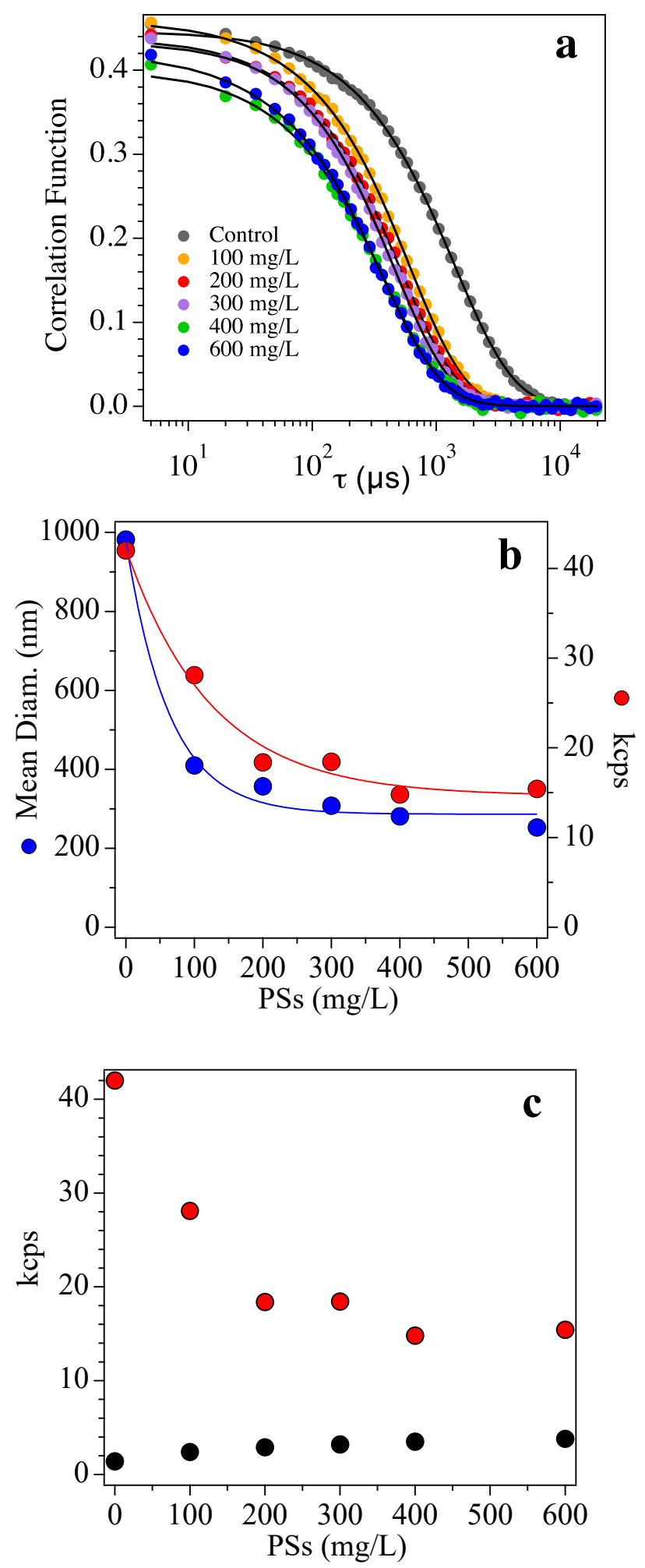

Figure 5. Panel (a): correlation functions of the heated samples (dots) along with the CONTIN fit (black lines) vs. the delay time $(\tau)$. Panel $(\mathbf{b})$ : mean diameters (blue) obtained from the fitting of the curves with the CONTIN algorithm together with the number of scattered photons (kilo counts per second (kcps), red). Lines are the best fit according to the exponential function reported in the text. Panel (c): comparison between the number of scattered photons in the heated (red) and not heated (black) samples. 


\section{Conclusions}

According to our knowledge, this is the first time that Sch. japonicus PSs, after being recovered from the growth media by ultrafiltration, have been tested to assess their efficiency on wine protein stability. The results obtained in the present study have clearly shown that these PSs are able to improve wine protein heat stability. In particular, they are able to reduce the protein haze to around half of the initial values.

The reduction of the haze particles' size together with the solubility persistence of the heat instable wine proteins following the heat treatment confirm that an addition of these macromolecules into instable wine interferes with the protein aggregation process. To a certain extent, these PSs are able to protect wine from protein haze in a dose-dependent manner. However, further studies are still necessary to characterize and identify the active components of the pool of macromolecules released into the media, to understand their role in the protein haze protection and to evaluate their impact on other chemical, physical, and organoleptic wine features.

Author Contributions: Conceptualization, P.D.; Data curation, V.M., G.F., A.A. and P.D.; Formal analysis, V.M., S.I., S.C., G.F., A.A. and P.D.; Funding acquisition, E.F. and P.D.; Methodology, E.F. and P.D.; Supervision, P.D.; Visualization, P.D.; Writing—original draft, P.D.; Writing—review \& editing, V.M., G.F., B.Z., E.F. and P.D. All authors have read and agreed to the published version of the manuscript.

Funding: This research received no external funding.

Acknowledgments: P.D. acknowledges partial financial support from Enartis-Esseco srl, (Via S. Cassiano 99, 28069 Trecate, Italy) and Giovanni Cappelli (Castello di Querceto, Via Alessandro François, 2-50022 Firenze-Italy) for providing the wines. G.F. and E.F. acknowledge partial financial support from Consorzio per lo sviluppo dei Sistemi a Grande Interfase (CSGI) and MIUR ("Progetto Dipartimenti di Eccellenza 2018-2022" allocated to Department of Chemistry "Ugo Schiff").

Conflicts of Interest: The authors declare no conflict of interest.

\section{References}

1. Dordoni, R.; Colangelo, D.; Giribaldi, M.; Giuffrida, M.G.; De Faveri, D.M.; Lambri, M. Effect of Bentonite Characteristics on Wine Proteins, Polyphenols, and Metals under Different pH Conditions. Am. J. Enol. Vitic. 2015, 66, 518-530. [CrossRef]

2. Making Good Wine. Available online: https://www.panmacmillan.com.au/9781405036016/ (accessed on 1 May 2004).

3. Høj, P.B.; Tattersall, D.B.; Adams, K.; Pocock, K.F.; Hayasaka, Y.; van Heeswijck, R.; Waters, E. The ‘haze proteins' of wine-A summary of properties, factors affecting their accumulation in grapes, and the amount of bentonite required for their removal from wine. In Proceedings of the ASEV 50th Anniversary Meeting, Seattle, WA, USA, 19-23 June 2000.

4. Lambri, M.; Dordoni, R.; Silva, A.; De Faveri, D.M. Odor-active compound adsorption onto bentonite in a model white wine solution. Chem. Eng. Trans. 2013, 32, 1741-1746.

5. Francis, I.L.; Sefton, M.A.; Williams, P.J. The sensory effects of pre- or post-fermentation thermal processing on Chardonnay and Semillon wines. Am. J. Enol. Vitic. 1994, 45, 243-251.

6. Pocock, K.; Høj, P.; Adams, K.; Kwiatkowski, M.; Waters, E. Combined heat and proteolytic enzyme treatment of white wines reduces haze forming protein content without detrimental effect. Aust. J. Grape Wine Res. 2003, 9, 56-63. [CrossRef]

7. Hsu, J.-C.; Heatherbell, D.A.; Flores, J.H.; Watson, B.T. Heat-unstable proteins in grape juice and wine. II. Characterization and removal by ultrafiltration. Am. J. Enol. Vitic. 1987, 38, 17-22.

8. Flores, J.H.; Heatherbell, D.A.; McDaniel, M.R. Ultrafiltration of wine: Effect of ultrafiltration on white Riesling and Gewürztraminer wine composition and stability. Am. J. Enol. Vitic. 1990, 41, 207-214.

9. Marangon, M.; Van Sluyter, S.C.; Robinson, E.M.; Muhlack, R.A.; Holt, H.E.; Haynes, P.A.; Godden, P.W.; Smith, P.; Waters, E. Degradation of white wine haze proteins by Aspergillopepsin I and II during juice flash pasteurization. Food Chem. 2012, 135, 1157-1165. [CrossRef] 
10. Van Sluyter, S.C.; Warnock, N.I.; Schmidt, S.A.; Anderson, P.A.; Van Kan, J.A.L.; Bacic, A.; Waters, E.J. Aspartic Acid Protease from Botrytis cinerea Removes Haze-Forming Proteins during White Winemaking. J. Agric. Food Chem. 2013, 61, 9705-9711. [CrossRef]

11. Sarmento, M.R.; Boulton, R.B.; Oliveira, J.C. Selection of low swelling materials for protein adsorption from white wines. Int. J. Food Sci. Technol. 2000, 35, 41-47. [CrossRef]

12. Pashova, V.; Güell, C.; López, F. White Wine Continuous Protein Stabilization by Packed Column. J. Agric. Food Chem. 2004, 52, 1558-1563. [CrossRef]

13. Salazar, F.N.; Achaerandio, I.; Labbé, M.A.; Güell, C.; López, F. Comparative study of protein stabilization in white wine using zirconia and bentonite: Physiochemical and wine sensory analysis. J. Agric. Food Chem. 2006, 54, 9955-9958. [CrossRef] [PubMed]

14. Marangon, M.; Lucchetta, M.; Waters, E. Protein stabilization of white wines using zirconium dioxide enclosed in a metallic cage. Aust. J. Grape Wine Res. 2010, 17, 28-35. [CrossRef]

15. Lucchetta, M.; Pocock, K.F.; Waters, E.; Marangon, M. Use of Zirconium Dioxide during Fermentation as an Alternative to Protein Fining with Bentonite for White Wines. Am. J. Enol. Vitic. 2013, 64, 400-404. [CrossRef]

16. Mercurio, M.; Mercurio, V.; Gennaro, B.; Gennaro, M.; Grifra, C.; Langella, A.; Morra, V. Natural zeolites and white wines from Campania region (Southern Italy): A new contribution for solving some oenological problems. Period Miner. 2010, 79, 95-112.

17. Mierczynska-Vasilev, A.; Wahono, S.K.; Smith, P.A.; Bindon, K.; Vasilev, K. Using Zeolites To Protein Stabilize White Wines. ACS Sustain. Chem. Eng. 2019, 7, 12240-12247. [CrossRef]

18. Vincenzi, S.; Mosconi, S.; Zoccatelli, G.; Pellegrina, C.D.; Veneri, G.; Chignola, R.; Peruo, A.; Curioni, A.; Rizzi, C. Development of a new procedure for protein recovery and quantification in wine. Am. J. Enol. Vitic. 2005, 56, 182-187.

19. Colangelo, D.; Torchio, F.; De Faveri, D.M.; Lambri, M. The use of chitosan as alternative to bentonite for wine fining: Effects on heat-stability, proteins, organic acids, colour, and volatile compounds in an aromatic white wine. Food Chem. 2018, 264, 301-309. [CrossRef]

20. Vincenzi, S.; Polesani, M.; Curioni, A. Removal of specific protein components by chitin enhances protein stability in a white wine. Am. J. Enol. Vitic. 2005, 56, 246-254.

21. Spagna, G.; Pifferi, P.G.; Rangoni, C.; Mattivi, F.; Nicolini, G.; Palmonari, R. The stabilization of white wines by adsorption of phenolic compounds on chitin and chitosan. Food Res. Int. 1996, 29, 241-248. [CrossRef]

22. Ratnayake, S.; Stockdale, V.; Grafton, S.; Munro, P.; Robinson, A.L.; Pearson, W.; McRae, J.M.; Bacic, A. Carrageenans as heat stabilizers of white wine. Aust. J. Grape Wine Res. 2019, 25, 439-450. [CrossRef]

23. Marangon, M.; Stockdale, V.J.; Munro, P.; Trethewey, T.; Schulkin, A.; Holt, H.E.; Smith, P. Addition of Carrageenan at Different Stages of Winemaking for White Wine Protein Stabilization. J. Agric. Food Chem. 2013, 61, 6516-6524. [CrossRef] [PubMed]

24. Marangon, M.; Lucchetta, M.; Duan, D.; Stockdale, V.; Hart, A.; Rogers, P.; Waters, E. Protein removal from a Chardonnay juice by addition of carrageenan and pectin. Aust. J. Grape Wine Res. 2012, 18, 194-202. [CrossRef]

25. LeDoux, V.; Dulau, L.; Dubourdieu, D. Interprétation de l'amélioration de la stabilité protéique des vins au cours de l'élevage sur lies. J. Int. Sci. Vigne Vin. 1992, 26, 239. [CrossRef]

26. Waters, E.J.; Wallace, W.; Tate, M.E.; Williams, P.J. Isolation and partial characterization of a natural haze protective factor from wine. J. Agric. Food Chem. 1993, 41, 724-730. [CrossRef]

27. Waters, E.J.; Pellerin, P.; Brillouet, J.-M. A Saccharomyces mannoprotein that protects wine from protein haze. Carbohydr. Polym. 1994, 23, 185-191. [CrossRef]

28. Moine-Ledoux, V.; Dubourdieu, D. An invertase fragment responsible for improving the protein stability of dry white wines. J. Sci. Food Agric. 1999, 79, 537-543. [CrossRef]

29. Dupin, I.V.; McKinnon, B.M.; Ryan, C.; Boulay, M.; Markides, A.J.; Jones, G.P.; Williams, P.J.; Waters, E. Saccharomyces cerevisiae mannoproteins that protect wine from protein haze: Their release during fermentation and lees contact and a proposal for their mechanism of action. J. Agric. Food Chem. 2000, 48, 3098-3105. [CrossRef]

30. Brown, S.L.; Stockdale, V.J.; Pettolino, F.; Pocock, K.F.; Lopes, M.D.B.; Williams, P.J.; Bacic, A.; Fincher, G.B.; Høj, P.B.; Waters, E. Reducing haziness in white wine by overexpression of Saccharomyces cerevisiae genes YOL155c and YDR055w. Appl. Microbiol. Biotechnol. 2007, 73, 1363-1376. [CrossRef]

31. Carvalho, E.; Mateus, N.; Plet, B.; Pianet, I.; Dufourc, E.; De Freitas, V. Influence of Wine Pectic Polysaccharides on the Interactions between Condensed Tannins and Salivary Proteins. J. Agric. Food Chem. 2006, 54, 8936-8944. [CrossRef] 
32. Vidal, S.; Francis, I.; Williams, P.; Kwiatkowski, M.; Gawel, R.; Cheynier, V.; Waters, E. The mouth-feel properties of polysaccharides and anthocyanins in a wine like medium. Food Chem. 2004, 85, 519-525. [CrossRef]

33. Chalier, P.; Angot, B.; Delteil, D.; Doco, T.; Günata, Z. Interactions between aroma compounds and whole mannoprotein isolated from Saccharomyces cerevisiae strains. Food Chem. 2007, 100, 22-30. [CrossRef]

34. Guadalupe, Z.; Ayestarán, B. Polysaccharide Profile and Content during the Vinification and Aging of Tempranillo Red Wines. J. Agric. Food Chem. 2007, 55, 10720-10728. [CrossRef] [PubMed]

35. Gonzalez-Ramos, D.; Cebollero, E.; Gonzalez, R. A Recombinant Saccharomyces cerevisiae Strain Overproducing Mannoproteins Stabilizes Wine against Protein Haze. Appl. Environ. Microbiol. 2008, 74,5533-5540. [CrossRef] [PubMed]

36. Lubbers, S.; Léger, B.; Charpentier, C.; Feuillat, M. Effet colloïdes protecteurs d'extraits de parois de levures sur la stabilité tartrique d'un vin modèle. J. Int. Sci. Vigne Vin 1993, 27, 13-22.

37. Vidal, S.; Williams, P.; Doco, T.; Moutounet, M.; Pellerin, P. The polysaccharides of red wine: Total fractionation and characterization. Carbohydr. Polym. 2003, 54, 439-447. [CrossRef]

38. Klis, F.M.; Boorsma, A.; Grootab, P.W. Cell wall construction in Saccharomyces cerevisiae. Yeast 2006, 23, 185-202. [CrossRef] [PubMed]

39. Llaubères, R.M.; Dubourdieu, D.; Villetaz, J.C. Exocellular polysaccharides from Saccharomyces cerevisiae in wine. J. Sci. Food Agric. 1987, 41, 277-286. [CrossRef]

40. Charpentier, C.; Feuillat, M. Wine Microbiology and Biotechnology; Harwood Academic Publishers: Chur, Switzerland, 1993; pp. 225-242.

41. Boivin, S.; Feuillat, M.; Alexandre, H.; Charpentier, C. Effect of must turbidity on cell wall porosity and macromolecules excretion of Saccharomyces cerevisiae cultivated on grape juice. Am. J. Enol. Vitic. 1998, 49, 325-332.

42. Charpentier, C.; Dos Santos, A.; Feuillat, M. Release of macromolecules by Saccharomyces cerevisiae during ageing of French flor sherry wine "Vin jaune". Int. J. Food Microbiol. 2004, 96, 253-262. [CrossRef]

43. Waters, E.; Alexander, G.; Muhlack, R.; Pocock, K.; Colby, C.; O’Neill, B.; Høj, P.; Jones, P. Preventing protein haze in bottled white wine. Aust. J. Grape Wine Res. 2005, 11, 215-225. [CrossRef]

44. Ribeiro, T.; Fernandes, C.; Nunes, F.M.; Filipe-Ribeiro, L.; Cosme, F. Influence of the structural features of commercial mannoproteins in white wine protein stabilization and chemical and sensory properties. Food Chem. 2014, 159, 47-54. [CrossRef] [PubMed]

45. Young, M.; Davies, M.J.; Bailey, D.; Gradwell, M.J.; Smestad-Paulsen, B.; Wold, J.K.; Barnes, R.M.; Hounsell, E.F. Characterization of oligosaccharides from an antigenic mannan of Saccharomyces cerevisiae. Glycoconj. J. 1998, 15, 815-822. [CrossRef] [PubMed]

46. Rosi, I.; Gheri, A.; Domizio, P.; Fia, G. Production de macromolecules parietals de Saccharomyces cerevisiae au cours de la fermentation et leur influence sur la fermentation malolactique. Rev. Des. Oenol. 2000, 94, 18-20.

47. Romani, C.; Domizio, P.; Lencioni, L.; Gobbi, M.; Comitini, F.; Ciani, M.; Mannazzu, I. Polysaccharides and glycerol production by non-Saccharomyces wine yeasts in mixed fermentation. Quad. Vitic. Enol. Univ. Torino 2010, 31, 185-189.

48. Domizio, P.; Romani, C.; Lencioni, L.; Comitini, F.; Gobbi, M.; Mannazzu, I.; Ciani, M. Outlining a future for non-Sacharomyces yeasts: Selection of putative spoilage wine strains to be used in association with Saccharomyces cerevisiae for grape juice fermentation. Int. J. Food Microbiol. 2011, 147, 170-180. [CrossRef]

49. Domizio, P.; Romani, C.; Comitini, F.; Gobbi, M.; Lencioni, L.; Mannazzu, I.; Ciani, M. Potential spoilage non-Saccharomyces yeasts in mixed cultures with Saccharomyces cerevisiae. Ann. Microbiol. 2010, 61, 137-144. [CrossRef]

50. Domizio, P.; Liu, Y.; Bisson, L.; Barile, D. Use of non-Saccharomyces wine yeasts as novel sources of mannoproteins in wine. Food Microbiol. 2014, 43, 5-15. [CrossRef] [PubMed]

51. Domizio, P.; Liu, Y.; Bisson, L.; Barile, D. Cell wall polysaccharides released during the alcoholic fermentation by Schizosaccharomyces pombe and S. japonicus: Quantification and characterization. Food Microbiol. 2016, 61, 136-149. [CrossRef]

52. Comitini, F.; Gobbi, M.; Domizio, P.; Romani, C.; Lencioni, L.; Mannazzu, I.; Ciani, M. Selected non-Saccharomyces wine yeasts in controlled multistarter fermentations with Saccharomyces cerevisiae. Food Microbiol. 2011, 28, 873-882. [CrossRef]

53. Domizio, P.; Lencioni, L.; Calamai, L.; Portaro, L.; Bisson, L. Evaluation of the Yeast Schizosaccharomyces japonicus for Use in Wine Production. Am. J. Enol. Vitic. 2018, 69, 266-277. [CrossRef] 
54. Spiropoulos, A.; Tanaka, J.; Flerianos, I.; Bisson, L.F. Characterization of hydrogen sulfide formation in commercial and natural wine isolates of Saccharomyces. Am. J. Enol. Vitic. 2000, 51, 233-248.

55. Romani, C.; Lencioni, L.; Bartolini, A.B.; Ciani, M.; Mannazzu, I.; Domizio, P. Pilot Scale Fermentations of Sangiovese: An Overview on the Impact of Saccharomyces and Non-Saccharomyces Wine Yeasts. Fermentation 2020, 6, 63. [CrossRef]

56. Chamizo, S.; Adessi, A.; Mugnai, G.; Simiani, A.; De Philippis, R. Soil Type and Cyanobacteria Species Influence the Macromolecular and Chemical Characteristics of the Polysaccharidic Matrix in Induced Biocrusts. Microb. Ecol. 2018, 78, 482-493. [CrossRef] [PubMed]

57. Bradford, M.M. A rapid and sensitive method for the quantitation of microgram quantities of protein utilizing the principle of protein-dye binding. Anal. Biochem. 1976, 72, 248-254. [CrossRef]

58. McRae, J.M.; Barricklow, V.; Pocock, K.; Smith, P. Predicting protein haze formation in white wines. Aust. J. Grape Wine Res. 2018, 24, 504-511. [CrossRef]

59. Laemmli, U.K. Cleavage of Structural Proteins during the Assembly of the Head of Bacteriophage T4. Nature 1970, 227, 680-685. [CrossRef] [PubMed]

60. Packer, N.H.; Ball, M.S.; Devine, P.L.; Patton, W.F. The Protein Protocols Handbook Walker. In Detection of Glycoproteins in Gels and Blots; Humana Press: Totowa, NJ, USA, 2002; pp. 761-772.

61. Ju, R.T.C.; Frank, C.W.; Gast, A.P. CONTIN analysis of colloidal aggregates. Langmuir 1992, 8, $2165-2171$. [CrossRef]

62. Manners, D.J.; Meyer, M.T. The molecular structures of some glucans from the cell walls of Schizosaccharomyces pombe. Carbohydr. Res. 1977, 57, 189-203. [CrossRef]

63. Hart, C.; Schulenberg, B.; Steinberg, T.H.; Leung, W.-Y.; Patton, W.F. Detection of glycoproteins in polyacrylamide gels and on electroblots using Pro-Q Emerald 488 dye, a fluorescent periodate Schiff-base stain. Electrophoresis 2003, 24, 588-598. [CrossRef]

64. Pellerin, P.; Waters, E.; Brillouet, J.-M.; Moutounet, M. Effet de polysaccharides sur la formation de trouble protéique dans un vin blanc. J. Int. Sci. Vigne Vin 1994, 28, 213. [CrossRef]

65. Iland, P.G.; Ewart, A.J.W.; Sitters, J.H.; Markides, A.J.; Bruer, N.G.C. Techniques for Chemical Analysis and Quality Monitoring During Winemaking; Patrick Iland Wine Promotions: Campbelltown, Australia, 2000.

66. Robinson, S.P.; Davies, C. Molecular biology of grape berry ripening. Aust. J. Grape Wine Res. 2000, 6, 175-188. [CrossRef]

67. Ferreira, R.B.; A Piçarra-Pereira, M.; Monteiro, S.A.; Loureiro, V.B.; Teixeira, A.R. The wine proteins. Trends Food Sci. Technol. 2001, 12, 230-239. [CrossRef]

68. Van Sluyter, S.C.; McRae, J.M.; Falconer, R.J.; Smith, P.; Bacic, A.; Waters, E.J.; Marangon, M. Wine Protein Haze: Mechanisms of Formation and Advances in Prevention. J. Agric. Food Chem. 2015, 63, 4020-4030. [CrossRef] [PubMed]

69. Cosme, F.; Fernandes, C.; Ribeiro, T.; Filipe-Ribeiro, L.; Nunes, F.M. White Wine Protein Instability: Mechanism, Quality Control and Technological Alternatives for Wine Stabilization-An Overview. Beverages 2020, 6, 19. [CrossRef]

70. Dufrechou, M.; Vernhet, A.; Roblin, P.; Sauvage, F.-X.; Poncet-Legrand, C. White Wine Proteins: How Does the $\mathrm{pH}$ Affect Their Conformation at Room Temperature? Langmuir 2013, 29, 10475-10482. [CrossRef] [PubMed]

71. Dufrechou, M.; Doco, T.; Poncet-Legrand, C.; Sauvage, F.-X.; Vernhet, A. Protein/Polysaccharide Interactions and Their Impact on Haze Formation in White Wines. J. Agric. Food Chem. 2015, 63, 10042-10053. [CrossRef] [PubMed]

72. Vernhet, A.; Pellerin, P.; Prieur, C.; Osmianski, J.; Moutounet, M. Charge properties of some grape and wine polysaccharide and polyphenolic fractions. Am. J. Enol. Vitic. 1996, 47, 25-30.

73. Hassan, P.A.; Rana, S.; Verma, G. Making Sense of Brownian Motion: Colloid Characterization by Dynamic Light Scattering. Langmuir 2014, 31, 3-12. [CrossRef]

(C) 2020 by the authors. Licensee MDPI, Basel, Switzerland. This article is an open access article distributed under the terms and conditions of the Creative Commons Attribution (CC BY) license (http://creativecommons.org/licenses/by/4.0/). 